\title{
Trace Element Evaluation of Groundwater in Douala, Cameroon
}

\author{
Ngwese Sharon Ntube, Aduck Jovens Nyangang, Ma-Effeti Ngale Agbor, \\ Akoachere Richard Ayuk II* (1) \\ Department of Geology, University of Buea, Buea, Cameroon \\ Email: *r.akoachere@ubuea.cm
}

How to cite this paper: Ntube, N.S., Nyangang, A.J., Agbor, M.-E.N. and Ayuk II, A.R. (2022) Trace Element Evaluation of Groundwater in Douala, Cameroon. Open Access Library Journal, 9: e8267.

https://doi.org/10.4236/oalib.1108267

Received: December 2, 2021

Accepted: January 11, 2022

Published: January 14, 2022

Copyright $\odot 2022$ by author(s) and Open Access Library Inc.

This work is licensed under the Creative Commons Attribution International License (CC BY 4.0).

http://creativecommons.org/licenses/by/4.0/ (c) (i) Open Access

\begin{abstract}
Douala, situated between latitude 4.00 - 4.15 and longitude $9.65-9.95$, is the economic capital of Cameroon in the Littoral Region and it hosts more than $80 \%$ of the industries in the Country. Increased urbanization and agricultural activities have a potential for trace metal contamination as such, the trace metal evaluation of groundwater in Douala begs our attention. This study investigated the trace metal content of groundwater sources; determined estimates of the health hazard and pollution risk indices; assessed the health hazard and level of risk to trace metal pollution in Douala. Measurement of 153 hand-dug wells for physicochemical parameters and chemical analysis of 10 representative groundwater samples was carried out to determine their trace metal content using Inductively Coupled Plasma Mass Spectroscopy ICP-MS. R-mode statistical analysis; Hierarchical Cluster Analysis (HCA) and Pearson's correlation analysis (PCA) of the trace metals to the physico-chemical parameters were done. Four pollution hazards were estimated; the average daily dose $\mathrm{ADD}$, carcinogenic risks $\mathrm{CR}$, non-carcinogenic risk hazard quotient HQ and hazard index HI. Six pollution risks indices were determined: the Degree of contamination DC, Enrichment factor EF, Ecological risk factor Er, Ecological risk index RI, Pollution load index PLI, and geo-accumulation index Igeo. The trace elements detected in groundwater in Douala and their relative abundance in decreasing order are: $\mathrm{Si}>\mathrm{Al}>\mathrm{Sb}>\mathrm{Sr}>\mathrm{Ba}>\mathrm{Mn}>\mathrm{Li}>$ $\mathrm{Zn}>\mathrm{As}>\mathrm{Bi}>\mathrm{Cr}>\mathrm{Fe}>\mathrm{Se}>\mathrm{Ag}>\mathrm{Mo}>\mathrm{Ni}>\mathrm{Pb}>\mathrm{Sn}>\mathrm{Ti}>\mathrm{TI}>\mathrm{V}$. HCA distinguishes trace metals into two clusters: Cluster1; $\mathrm{Li}, \mathrm{Zn}, \mathrm{Sr}, \mathrm{Sb}, \mathrm{Al}, \mathrm{TI}, \mathrm{V}$, $\mathrm{Ti}, \mathrm{Sn}, \mathrm{Pb}, \mathrm{Mo}, \mathrm{Ni}, \mathrm{Ag}, \mathrm{Cd}, \mathrm{Co}, \mathrm{Cu}, \mathrm{U}, \mathrm{Y}, \mathrm{Ba}, \mathrm{Mn}, \mathrm{Cr}, \mathrm{Se}, \mathrm{Bi}, \mathrm{As}$, Fe and Cluster2 $\mathrm{Si}$. The values of groundwater pollution hazard indices ranged; ADD (0 $60 \mathrm{mg} / \mathrm{kg} /$ day), CR (0 - 13), HQ (1.0E05 - 1.1E05) and HI (1.05E04 - 1.2E04). The values of the pollution risk indices are DC $(-1.93-1.91)$, EF $(0.0-1.2)$, $\operatorname{Er}(-5-0)$, RI $(-17.58--17.64)$, PLI $(-0.13-0.13)$ and Igeo $(0-1.16)$. The Health risk assessment qualified groundwater in Douala as unsafe and intol-
\end{abstract}


erable for human consumption but without carcinogenic effects. Pollution indices placed groundwater in Douala in the low degree background contamination with minimal enrichment, low potential ecological risk and geogenically unpolluted to moderately polluted. Very strong correlations were observed among some of the trace element pairs, suggesting common sources, mutual dependence and identical behaviour from provenance and during transport. The severity of trace element toxicity is governed by several factors, such as dose, nutrition, age, and life style. Therefore, these low trends might not guarantee human health due to an increasing level of environmental pollution that might be imposed by increasing human activity on Douala City and environs which might contaminate the groundwater; this demand for monitoring of groundwater sources for drinking purposes.

\section{Subject Areas}

Environmental Sciences, Geology, Hydrology

\section{Keywords}

Trace-Elements-Evaluation, Health-Risks-Assessment, Pollution-Indices, Douala-Cameroon

\section{Introduction}

Douala situated between latitude $4.00-4.15$ and longitude $9.65-9.95$, is the economic capital of Cameroon in the Littoral Region and it hosts more than $80 \%$ of the industries in the Country. Douala is the headquarters of the Wouri Division of the Littoral Region of Cameroon. It has a surface area of about 12805 $\mathrm{km}^{2}$. It is situated at elevation 19 meters above sea level. It is divided into districts: Akwa, Akwa-nord, Bepanda, Deido, Valle Besengue, Cite Sic, Ndongbong, Yabassi camp, Newbell, Babylon, Ngangue, Nyalla, as seen in Figure 1 [1]. This city handles most of the country's major exports, such as palm oil, cocoa, coffee, timber, metals, and fruits. According to [2], Douala hosts the largest urban population in the country with a population density of 350 persons per $\mathrm{km}^{2}$. Inadequate supply of pipe-borne water with only 65.000 persons connected to the water supply out of 3 million inhabitants forces the population to depend on groundwater. In Douala, groundwater is the major source of water supply for a large part of the population. Trace elements are one of the most serious contaminant groups of elements. The ecosystem has been contaminated by high concentration of heavy metals released into the biosphere by human activity. The term "trace elements" refers to chemical elements present in a natural material at concentrations less than 10 parts per million. Trace elements occur in low concentrations, in mass fractions of ppm or less, in soil, organisms and water [3]. Trace elements like Chromium, cobalt, copper, iron, manganese, magnesium, molybdenum, selenium, zinc, and other elements occur as constituents of living 


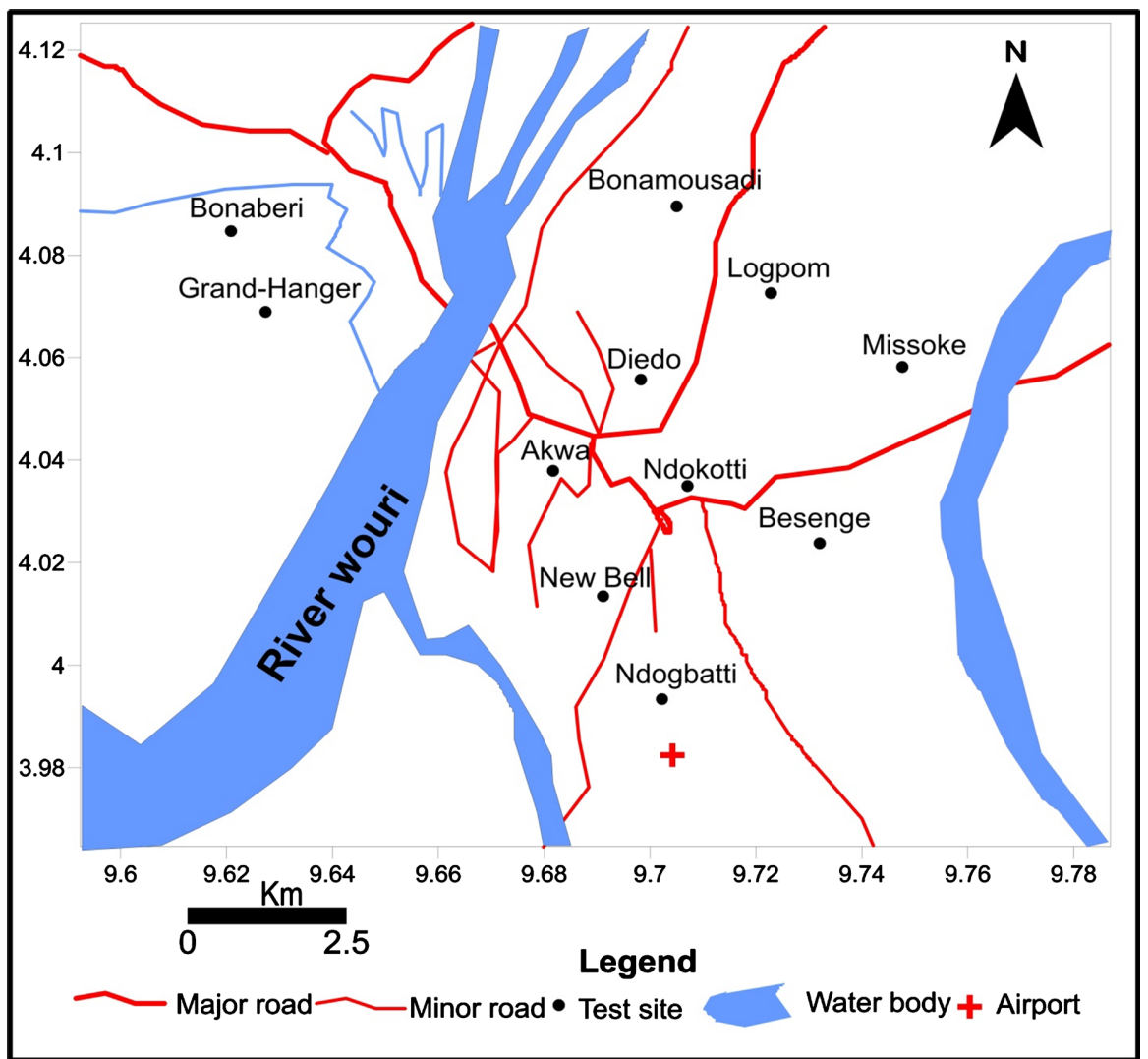

Figure 1. Sampled points of packaged groundwater in Douala (insert Cameroon and Africa).

organisms, and are necessary for their growth, development, and health. Though the shortage of some trace elements in the body may result in stunted growth or even death, their presence in higher amounts is also harmful. Trace elements are essential as micronutrients for life processes in plants and microorganisms, while others have no known physiological activity, but they are proved to be harmful beyond a certain limit and can cause serious health threats when over accumulated over time [4]. Many authors have focused their research on surface and groundwater biological quality, hydrogeochemistry, groundwater hydraulics in Cameroon [5] [1] [6]; however, studies on trace elements in Douala are sparse. This study is aimed at evaluating the groundwater trace element concentrations in Douala.

\section{Climate}

The climate of Douala indicates a hyper humid climate modified by the relief of Mt. Cameroon with a long rainy season from March to November and a short dry season from December to February marked, especially on the coast by significant precipitation. The average daily temperatures had been collected each month for 30 years by the Douala City Council (1984 to 2014) and the average monthly temperature varies from $24.8^{\circ} \mathrm{C}$ in July and August to $27.7^{\circ} \mathrm{C}$ in February with an annual average of $26.4^{\circ} \mathrm{C}$. January and February are identified as the hottest months of the year [6]. 


\section{Soils and Vegetation}

The soils of Douala are generally sandy with a low water holding capacity. However, other types of ferralitic soils formed on the diversity of the present bedrock (basalt and gneiss) sometimes with clay content are observed. These soils are better suited to agriculture because of their chemical properties. The warm and humid climate of the city of Douala is conducive for the luxuriant development of dense forest, mangroves and some vegetable crops that regress the advancement of urban development.

Geologic setting of study area

The Douala Basin also called the Douala/Kribi-Campo Basin [7] is a divergent, marginal rift basin and one of the two Atlantic coastal basins of Cameroon, the other being the Rio del Rey Basin. These form part of a series of sedimentary fills lining the West African coast. Regionally, the Douala Basin is located at the northern end of the South Atlantic rift [8] and [9] included this basin as the eastern extension and part of a series of West African coastal basins. The basin therefore, is generally linked to both the South and Equatorial Atlantic and forms part of the Gulf of Guinea which extends from Angola to Senegal, representing the scar left on the African continent by the separation of South America [10]. The Douala Basin is made up of two sub-basins, the Douala Sub-Basin to the north and Kribi-Campo Sub-Basin to the south [7]. Generally, the Douala Basin is composed of non-marine and marine sediments that range from Berremian-Aptian till Resent, making up the on- and offshore portions of the basin. The two sub-basins present quite remarkable difference in their lithostratigraphic sequences.

The Douala Basin developed during the Cretaceous break-up of Gondwana and the separation of Africa from South America. The initial rifting phase may have started during very Early Cretaceous time (Berriasian-Hauterivian) but the principal rifting episode in these areas occurred from late Berremian-Aptian time. The initial formation of oceanic crust as the continents separated is believed to have commenced during the late Aptian-late Albian interval. It would appear that the rifting was asymmetrical, as many of the syn-rift features that would normally be expected are not apparent at depth in this area, but they are abundant in the corresponding South American segment. Several additional tectonic events occurred during the passive "drift" phase of the continental margin evolution at $84 \mathrm{Ma}$ (Santonian), $65 \mathrm{Ma}$ (K/T boundary) and $37 \mathrm{Ma}$ (late Eocene). These events, resulting in uplift, deformation and erosion at the basin margins, are generally attributed to changes in plate motion and intraplate stress fields due to convergent and collision events between Africa and Europe. The Santonian uplift and possibly the late Eocene events also appear to have resulted in significant mass wasting of the continental margin by gravity sliding, contributing towards reservoir formation. The final uplift event relates to the growth of the Cameroon Volcanic Line (CVL) and effectively lasts from $37 \mathrm{Ma}$ through to present day on the northwest margin of the basin. 
The basal formation in the Douala Sub-Basin is the Mundeck Formation [11]-[16] is Berremian-Aptian to Albian in age and unconformably overlies the Precambrian basement complex. It comprises basal conglomerates, conglomeritic sandstones, siltstones, claystones and shales that were deposited in a continental fluvio-lacustrine setting. The Logbajeck Formation, also known as the Mungo River Formation, is directly overlying the Mundeck Formation. It ranges in age from Cenomanian to early Campanian [17] and lithofacies include; sandstone, siltstone, limestone, marlstone and shale. Directly above the Logbajeck Formation lies the late Campanian-Maastrician Logbaba Formation made up of shale, sand and sandstone and in places, limestone, sandstone and shale alternate. The first Tertiary formation is the Paleocene-Eocene N'kapa Formation which is predominantly calcareous to slightly silty claystone that is locally inter-bedded with sanstone and glauconitic claystone. The Souelaba Formation overlies the N'kapa Formation and has been dated Oligocene-Miocene. It comprises claystone with inter-bedded sanstones and sands, locally calcareous, argillaceous and glauconitic. The next is the Matanda Formation whose age is dated Late Pliocene-Pleistocene. Its lithology is made up of gravels, sands with inter-bedded claystones and clays and sometimes calcareous. The basin is capped by the Pleistocene-Holocene Wouri Formation which directly overlies the Matanda Formation. It is exposed to sands, sandstones, claystones with local development of tuffs and lavas [18]. The main rock types in Douala City include; sandstones, limestone, shale, and alluvium [6] as in Figure 2

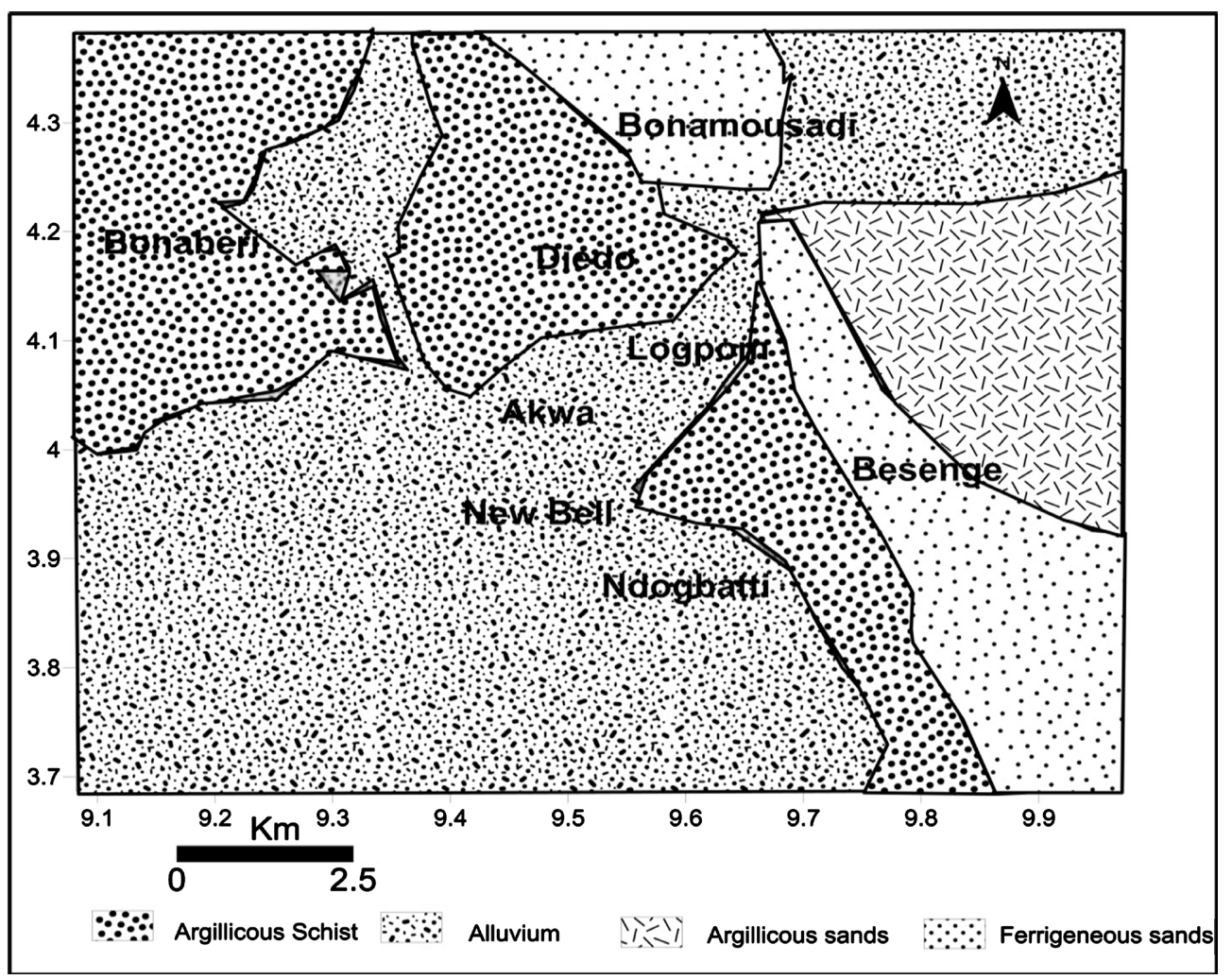

Figure 2. Geology of Douala and environs [1]. 


\section{Materials and Methods}

\subsection{Materials}

Materials, Equipment and their uses for this study are listed in Table 1.

\subsection{Groundwater Samples Collection, Preparation}

153 hand-dug wells including some rivers were located around the city of Douala. At each of the sites, a GPS was used to get readings of the coordinates of the locations. 10 groundwater samples were collected from 10 pre-selected wells.

Prior to sampling, the bottles were rinsed with the water to be sampled so as to avoid contamination. The well water was withdrawn with a small bucket on which a rope was tied on to reach water in the well.

The groundwater samples collected in $50 \mathrm{ml}$ were acidified and sent to Activation laboratory Canada for the determination of the concentrations of trace elements using ICP-OES analysis.

\subsection{Hazard Identification}

Involved identification of the chemical of concern and documenting its toxic effects on humans after contact and the characterization of potential contaminants and their relative mobility [19] as in Table 2.

Table 1. Field Equipment, Software, their specifications and functions used in the study.

\begin{tabular}{|c|c|c|}
\hline Equipment/Soft wares & Specifications & Functions \\
\hline Bike & Commercial Bikes & To transport to wells \\
\hline GPS & GARMIN MAP 60 Csx & To measure coordinates and elevation \\
\hline EC Meter & Hanna HI 98304/98303 & To measure Electrical Conductivity \\
\hline $\mathrm{pH}$ Meter & Hanna Hi 98127/98107 & To measure $\mathrm{pH}$ of water. \\
\hline Measuring Tape & Measuring Tape & Measurement of well diameter and depth. \\
\hline Digital Thermometer & Extech39240 $\left(-50 / 200^{\circ} \mathrm{C}\right)$ & To measure water temperature \\
\hline Total Dissolved Solid & Hanna HI 96301 & To measure Total dissolved solids \\
\hline Water sampler & Gallenkampf $500 \mathrm{ml}$ & To collect water sample from well \\
\hline Syringe & $50,100 \mathrm{ml}$ Polystyrene & Acidification and filtration of sample \\
\hline Nitric acid & 98\% Pure Nitric Acid & Preservation by acidifying to $\mathrm{pH}<2$ \\
\hline Filter & Cellulose Filter $0.2 \mu \mathrm{m}$ & Filtration of sample \\
\hline Sample bottles & (HDPE) $50 \mathrm{ml}$ & Transmission of sample to laboratory \\
\hline Tape \& bold marker & Permanent Tape/marker & Sealing and labeling of sample bottles \\
\hline Water Level Indicator & Solinst Model $102 \mathrm{M}$ & Static water levels of wells \\
\hline IBM SPSS Statistics & Version 25.0 & Statistical analysis for PCA \\
\hline Global Mapper & Version 11 & GIS Geolocation of wells \\
\hline Golden Surfer & Version 12 & GIS plotting spatial distribution \\
\hline Aqua & Version 15 & To analyze water chemistry \\
\hline Q GIS & Version 2.1.8 & For georeferncing and production of map \\
\hline
\end{tabular}


Table 2. Trace element and their effects [18].

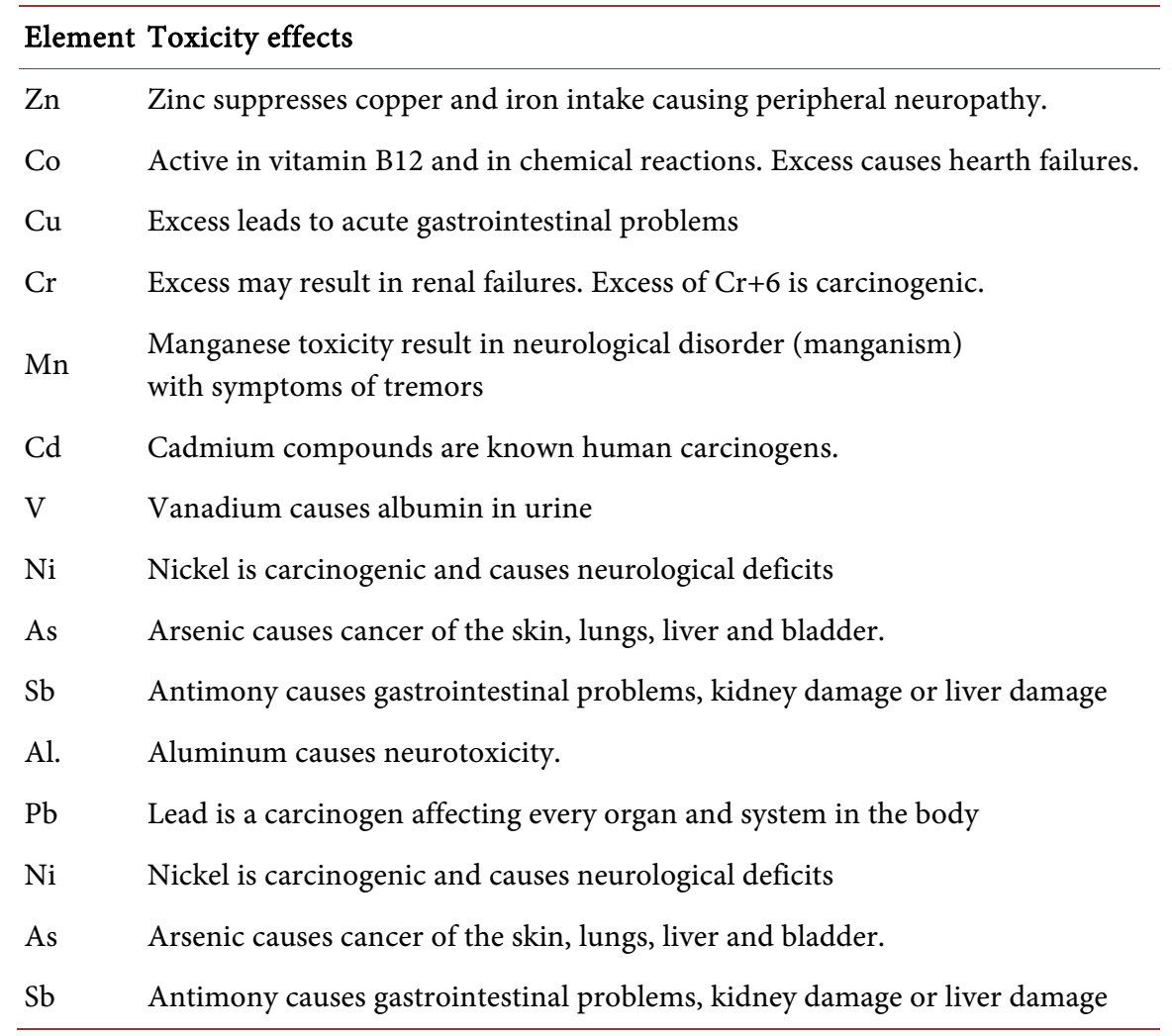

\subsection{Exposure Assessment}

This is the process of measuring or estimating the intensity, frequency and duration of human exposures to an environmental agent [19]. The main exposure pathway taken into consideration in this study was intake of the metals through water consumption. The daily environmental exposures to metals were assessed for carcinogenic and non-carcinogenic elements [20].

$$
\mathrm{ADD}=\frac{\mathrm{C} \cdot \mathrm{IR} \cdot \mathrm{ED} \cdot \mathrm{EF}}{\mathrm{BW} \cdot \mathrm{AT} \cdot 360}
$$

where;

ADDs are Exposure duration (mg/kg-day)-The Average Daily Dose (ADD) of the contaminant through water pathway indicates the quantity of chemical substance ingested per kilogram of body weight per day.

C: Concentration of contaminant in the environmental media (e.g, $\mu \mathrm{g} / \mathrm{L}$, $\mathrm{mg} / \mathrm{L})$.

IR: Ingestion rate per unit time (e.g. mg/day or L/day).

EF: Exposure frequency (day/year).

ED: Exposure duration (years).

BW: Body weight of receptor $(\mathrm{kg})$.

AT: Averaging time $=$ life expectancy (years) 365 is conversion factor from years to days.

For non-carcinogenic effects, $\mathrm{AT}=\mathrm{ED}$ in days; carcinogenic effect, $\mathrm{AT}=70$ 
years or 25,550 days.

\subsection{Dose-Response Assessment}

This is the quantitative relationship that indicates the contaminants degree of toxicity to exposed species. It also involves the identification of the toxicity criteria used to evaluate human health risk associated with the chemical of concern in the study area. The amount of chemical that can affect human health is estimated. The Reference Dose (RfD) is used for non-carcinogen risk.

\subsection{Risk Characterization}

This is the final phase of the risk assessment process. In this phase, cumulative exposure and dose-response assessments are integrated to yield probabilities of effects occurring in human beings under specific exposure conditions and time scales. Also incorporated is information from hazard identification, exposure assessment, toxicity assessment and risk estimation to evaluate the potential risk to residents.

\subsection{Carcinogenic Risk Assessment}

Carcinogenic risks were determined by calculating the potential of an individual to develop cancer as a result of cumulative exposure to each potential carcinogen over a lifetime. Carcinogenic properties were identified by a weight-of-evidence classification of the trace element concentration [21]. The estimated daily dose and the cancer slope factor are multiplied together to find the lifetime cancer risk posed by the chemical. Cancer slope factors are estimates of carcinogenic potency and were used to relate estimated daily dose of the trace metal over a lifetime exposure to the lifetime probability of excess tumors Equation (2) [22] [23].

$$
\mathrm{CR}=\mathrm{ADD} \cdot \mathrm{SF}
$$

where; CR is the excess probability of developing cancer over a lifetime as a result of exposure to a contaminator carcinogenic risk. It is unit less

$\mathrm{SF}$ is the slope factor of the contaminant $[\mathrm{mg} / \mathrm{kg} / \mathrm{d}]^{-1}$.

\subsection{Non Carcinogenic Risk Assessment}

Non-carcinogenic hazards are characterized by the hazard quotient (HQ). HQ is a unitless number that is expressed as the probability of an individual suffering an adverse effect. To estimate non carcinogenic risk, the hazard quotient (HQ) was calculated using Equation (3) [24].

$$
\mathrm{HQ}=\frac{\mathrm{ADD}}{\mathrm{RfD}}
$$

where; RfD is the reference dose $\mathrm{mg} / \mathrm{kg} / \mathrm{d}$. It represents a toxicity index of a daily exposure to the population in comparison to a safe level of exposure orally over a lifetime [25] 


\subsection{Hazard Index}

It is the toxic risks due to all the potentially hazardous substances present in the same media simultaneously [26]. Since more than one toxicant is evaluated, the interactions of all the toxicants were considered and assumed to be cumulative. Thus, the HI was calculated by summing the entire hazard quotient (HQ) for all toxicants, Equation (4) [22] [27].

$$
\mathrm{HI}=\sum_{i=1}^{n} \mathrm{HQ}_{i}
$$

\subsection{Pollution Risk Evaluation Indices}

Generally, pollution indices are estimated for a specific use of the water under consideration. The trace metal degree of contamination (DC), Contamination factor (CF), enrichment factor (EF), ecological risk index (Er), potential ecological risk index (RI), pollution load index (PLI) and geo-accumulation index (Igeo) were used to evaluate the pollution potential of Bafoussam as in Table 3.

Determination of Indices for contamination level assessment

The determination of indices for trace metal assessment includes the human health risk assessment indices and the pollution indices.

Human Health Risk Assessment Indices

A human health risk assessment estimates the nature and probability of adverse health effects in humans who may be exposed to chemicals in contaminated environmental media, now or in the future. Human health risk assessment includes 4 basic steps: EPA begins the process of a human health risk assessment with planning and research; hazard identification, dose-response assessment, exposure assessment, risk characterization

\section{Hazard identification}

This examines whether a stressor has the potential to cause harm to humans and /or ecological systems, and if so, under what circumstances.

Exposure assessment

The main exposure pathway taken into consideration in this study was intake of water through water consumption. The daily environmental exposure to metals was assessed for carcinogenic and non-carcinogenic elements. This is the process of measuring or estimating the intensity, frequency and duration of human exposures to an environmental agent [24]. The main exposure pathway taken into consideration in this study was intake of the metals through water consumption. The daily environmental exposures to metals were assessed for carcinogenic and non-carcinogenic elements. The procedures used to extrapolate from high to low doses are different for assessing carcinogenic effects and non-carcinogenic effects:

- Carcinogenic effects in general are not considered to have a threshold and mathematical models are generally used to provide estimates of carcinogenic risk at very low dose levels.

- Non-carcinogenic effects are considered to have dose thresholds below which the effect does not occur. The lowest dose with an effect in animal or human 
studies is divided by the safety factors to provide a margin of safety.

The primary health risk assessment classifications schemes are those of the Environmental Protection Agency [28]. The intake of metals through ingestion of groundwater was calculated (Equation (1)) [29].

$$
\mathrm{ADD}=\frac{\mathrm{C} \times \mathrm{IR} \times \mathrm{ED} \times \mathrm{EF}}{\mathrm{BW} \times \mathrm{AT} \times 360}
$$

where;

- ADDs: Exposure duration (mg/kg-day)

- The Average Daily Dose (ADD) is the amount of aqueous contaminant ingested per kilogram of body weight per day

- C: Concentration of contaminant in the environmental media (e.g., $\mu \mathrm{g} / \mathrm{L}$, $\mathrm{mg} / \mathrm{L})$

- IR: Ingestion rate per unit time (e.g., $\mathrm{mg} /$ day or L/day)

- EF: Exposure frequency (day/year)

- ED: Exposure duration (years)

- BW: Body weight of receptor $(\mathrm{kg})$

- AT: Averaging time = life expectancy (years) 365 is the conversion factor from years to days:

- For non-carcinogenic effects, $\mathrm{AT}=\mathrm{ED}$ in days. For carcinogenic effect, $\mathrm{AT}=$ 70 years or 25,550 days.

\subsection{Pollution Indices}

The geo-accumulation index $\left(I_{g e o}\right)$ is a quantitative measure of the degree of pollution in sediments. It renders seven degrees of contamination ranging from unpolluted to very extremely polluted conditions. To describe the level of pollution in the water, the formula of the $I_{g e o}$ is as follows:

$$
I_{\text {geo }}=\log _{2}\left[C_{i} /\left(1.5 C_{r i}\right)\right][17] \text {. }
$$

where $C_{n}$ is the metal concentration, and $B_{n}$ is the background geochemical value of a particular substance in the samples. Factor 1.5 is attributed to lessen the provable difference in the background values that may influence lithogenic effects. The $I_{g e o}$ values were categorized into 7 classes as in Table 3.

Table 3. Geo-accumulation index ( $\left.I_{g e o}\right)$ classification of groundwater in Douala.

\begin{tabular}{ccc}
\hline Class & Value & Status \\
\hline Class I & $I_{g e o}<0$ & Unpolluted \\
Class II & $0<I_{g e o}<1$ & Unpolluted to moderately polluted \\
Class III & $1<I_{g e o}<2$ & Moderately polluted \\
Class IV & $2<I_{g e o}<3$ & Moderately to heavily polluted \\
Class V & $3<I_{g e o}<4$ & heavily polluted \\
Class VI & $4<I_{g e o}<5$ & heavily to extremely polluted \\
Class VII & $I_{g e o}>5$ & Extremely polluted \\
\hline
\end{tabular}




\section{Results and Discussion}

\subsection{Chemical Suitability of Groundwater for Drinking}

The field measured physicochemical parameters of groundwater in Douala compared to the $\mathrm{WHO}$ guidelines for drinking water were as presented in Table 4. The Groundwater temperatures ranged from $22.9^{\circ} \mathrm{C}-36.7^{\circ} \mathrm{C}$ in the wet season and $24.1^{\circ} \mathrm{C}-37.8^{\circ} \mathrm{C}$ in the dry season; this is indicative that the wells are good for drinking. The $\mathrm{pH}$ ranges from 3.77 - 7.7 in the wet season and $3.64-7.4$ in the dry season; this is indicative that some of the well water in both seasons are not suitable for drinking. Some EC and TDS values of groundwater were above WHO permissible limit.

The results of chemical analysis of the major and minor elements of groundwater in Douala compared to WHO 2017 drinking water guidelines are as shown in Table 5.

Comparing average major cation and anion concentrations the groundwater in Douala is potable.

The results of the relevant trace elements in groundwater in Douala compared to the WHO guidelines and presented in Table 6.

Table 4. Physicochemical field parameters in compliance with [30] drinking water guidelines.

\begin{tabular}{cccccccc}
\hline \multirow{2}{*}{ Parameters } & \multicolumn{5}{c}{ Wet } & \multicolumn{5}{c}{ Dry } & [30] \\
\cline { 2 - 7 } & Min & Max & Mean & Min & Max & Mean & \\
\hline T $\left({ }^{\circ} \mathrm{C}\right)$ & 22.9 & 36.7 & 27.97 & 24.1 & 37.8 & 29.47 & $0-30$ \\
PH & 3.77 & 7.7 & 5.89 & 3.64 & 7.4 & 5.63 & $6.5-8.5$ \\
EC $(\mu \mathrm{S} / \mathrm{cm})$ & 10 & 1130 & 434.53 & 50 & 1000 & 407.56 & 750 \\
$\mathrm{TDS}(\mathrm{mg} / \mathrm{L})$ & 6.7 & 757.1 & 291.14 & 0 & 670 & 265.88 & 500 \\
$\mathrm{SWL}$ & 0.21 & 10.2 & 2 & 0.3 & 10.81 & 2.38 & \\
\hline
\end{tabular}

Table 5. Major and minor elements of groundwater in Douala compared to [30] drinking water guidelines.

\begin{tabular}{cccc}
\hline Parameter & Min & Max & {$[30]$} \\
\hline $\mathrm{TH}$ & 25.01 & 144.29 & 300 \\
$\mathrm{Ca}$ & 3.8 & 23.2 & 200 \\
$\mathrm{Mg}$ & 0.7 & 2.3 & 150 \\
$\mathrm{Na}$ & 5.6 & 54.6 & 200 \\
$\mathrm{~K}$ & 3.8 & 23.2 & 200 \\
$\mathrm{HCO}_{3}$ & 0 & 40.03 & 240 \\
$\mathrm{Cl}$ & 8.87 & 26.62 & 250 \\
$\mathrm{SO}_{4}$ & 10.01 & 68.08 & 250 \\
\hline
\end{tabular}


Table 6. Basic statistics of concentration of trace elements in groundwater in Douala $(\mu \mathrm{g} / \mathrm{L})$ compared to the WHO acceptable guidelines (values above guidelines in bold).

\begin{tabular}{|c|c|c|c|c|}
\hline Elements & $\operatorname{Max}$ & Min & Mean & [30] \\
\hline $\mathrm{Ba}$ & 0.17 & 0.02 & 0.06 & 0.07 \\
\hline $\mathrm{Al}$ & 1.9 & 0.10 & 0.31 & 0.2 \\
\hline $\mathrm{Mn}$ & 0.14 & 0.01 & 0.05 & 0.5 \\
\hline $\mathrm{Si}$ & 5.1 & 1.00 & 2.58 & 10 \\
\hline $\mathrm{Ag}$ & 0.01 & 0.01 & 0.01 & 0.1 \\
\hline As & 0.03 & 0.03 & 0.03 & 0.01 \\
\hline $\mathrm{Bi}$ & 0.02 & 0.02 & 0.02 & 0.2 \\
\hline $\mathrm{Cr}$ & 0.02 & 0.02 & 0.02 & 0.05 \\
\hline $\mathrm{Fe}$ & 0.05 & 0.01 & 0.02 & 2 \\
\hline $\mathrm{Li}$ & 0.05 & 0.05 & 0.05 & 0.2 \\
\hline Mo & 0.01 & 0.01 & 0.01 & 0.25 \\
\hline $\mathrm{Ni}$ & 0.01 & 0.01 & 0.01 & 0.7 \\
\hline $\mathrm{Pb}$ & 0.01 & 0.01 & 0.01 & 0.01 \\
\hline $\mathrm{Sb}$ & 0.31 & 0.26 & 0.28 & 0.02 \\
\hline $\mathrm{Se}$ & 0.02 & 0.02 & 0.02 & 0.05 \\
\hline Sn & 0.01 & 0.01 & 0.01 & 0.1 \\
\hline $\mathrm{Sr}$ & 0.20 & 0.02 & 0.07 & 4 \\
\hline $\mathrm{Ti}$ & 0.01 & 0.01 & 0.01 & 0.1 \\
\hline $\mathrm{Tl}$ & 0.01 & 0.01 & 0.01 & 0.2 \\
\hline V & 0.01 & 0.01 & 0.01 & 0.2 \\
\hline $\mathrm{Zn}$ & 0.09 & 0.03 & 0.05 & 2 \\
\hline
\end{tabular}

The values of $\mathrm{Ba}, \mathrm{Al}$, As and $\mathrm{Sb}$ were above the $\mathrm{WHO}$ guidelines as presented in Table 6. With the rapid industrialization and economic development, trace elements are being introduced to groundwater via several pathways viz; fertilization, irrigation, groundwater inflow and runoffs. The amount of trace elements in groundwater in Douala is generally low compared to the WHO guidelines but for $\mathrm{Ba}, \mathrm{AL}$, and $\mathrm{Sb}$ which are slightly higher. This is similar to the results of [26] in Ejisu-Juaben Municipality, Ghana.

\subsection{Human Health Risk Assessment}

This was done to assess the potentially harmful effects of long term human exposures to the low intensity and high frequency of the trace element concentration in groundwater used as drinking water in Douala so as to discriminate the health effects that might result from exposure to carcinogenic and non-carcinogenic chemicals. These health risk indices include ADD, CR, HQ and HI. 
1) For the average daily dose (ADD), values range from $0-60 \mathrm{mg} / \mathrm{kg} / \mathrm{day}$, amongst all the investigated trace elements, $\mathrm{Mn}$ and $\mathrm{Ag}$ have the highest or the greatest daily intake. All the other trace elements have acceptable to low average daily dose values as seen in Figure 3.

2) All the carcinogenic risk (CR). All values are $>10^{-4}$ and fall under the intolerable class; intollerable to human health. This implies that there is a tendency/ potential for the inhabitants in the Douala drinking groundwater over a long period to suffer from cancer as in Figure 4.

3) The non-carcinogenic hazard quotient (HQ) values were all found to be $>1$ using the USEPA 2012 [31] classification. This is indicative of no non-carcinogenic adverse effects in the groundwater in Douala as in Figure 5.

4) The carcinogenic hazard index (HI) values were found to be $>1$ as in Figure 6, according to USEPA, 2012 [31] classification. This indicates that the trace element concentrations in the groundwater in Douala is unsafe for human

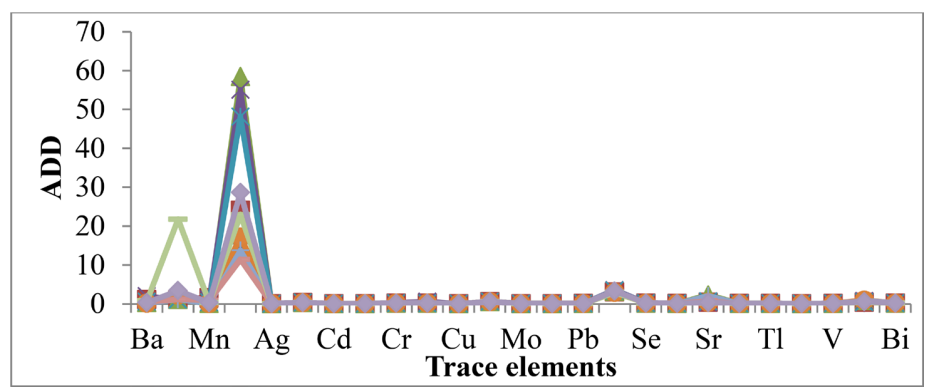

Figure 3. The average daily dose (ADD) of trace elements in Douala groundwater.

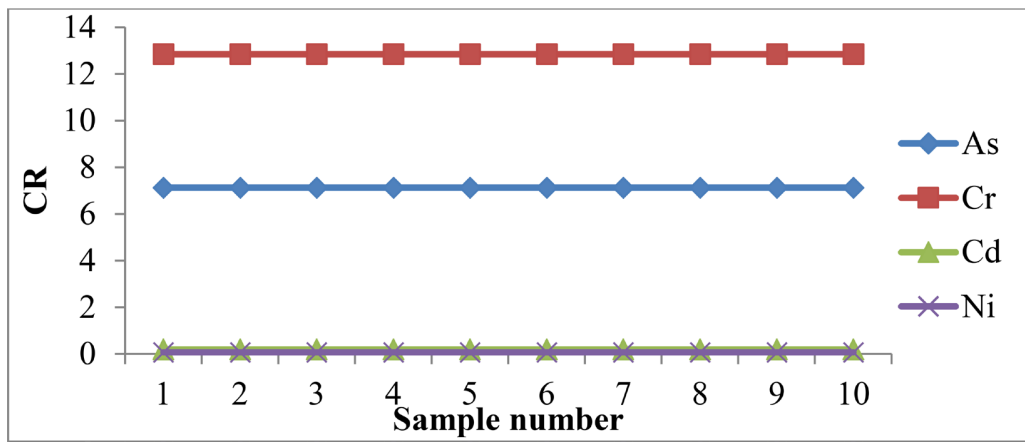

Figure 4. The carcinogenic risk (CR) of trace elements in Douala groundwater.

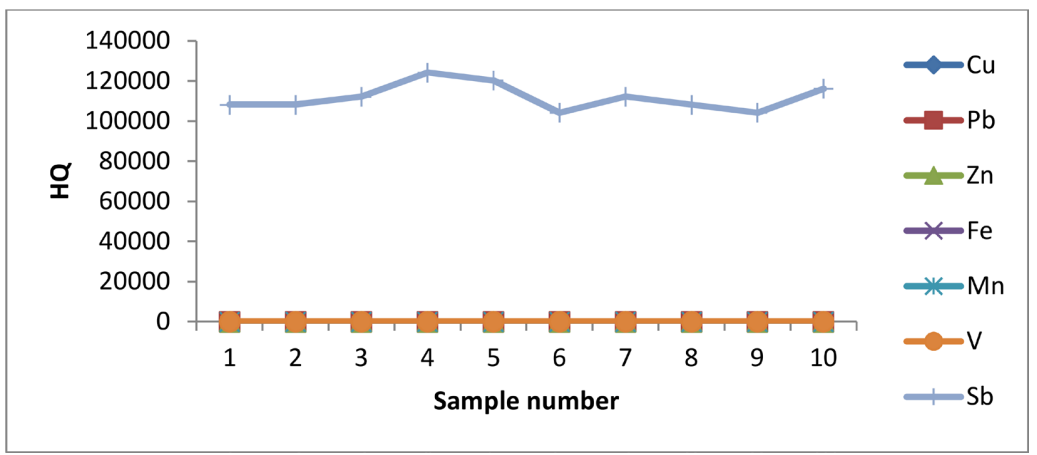

Figure 5. The non-carcinogenic hazard quotient of trace elements in Douala groundwater. 
consumption and may cause adverse effects to the human population with time.

The health risk assessment indices in the study area are below acceptable limits as presented in Table 7.

These results contrast those of [32] in Buea in the Piedmont regions of Mount Cameroon.

\subsection{Pollution Indices}

1) Geo-accumulation index (Igeo): The values for the trace elements in the groundwater in Douala are in the range of 0 - 1 of Class II, indicating unpolluted to moderately polluted groundwater. The maximum value of 0.15 moderately polluted groundwater geo-accumulation indexes is at Akwa Nord, New Bell and Ndogbati as in Figure 7.

2) Degree of contamination (DC) values shows low degree of contamination in the groundwater in Douala as in Figure 8. The low degree of contamination by these trace elements could be due to the absence of external discrete sources like agricultural runoff, other anthropogenic inputs or the occurrence of large volumes of groundwater flow through the Wouri delta (a discharge zone) on which Douala City is found which dilutes the effects of pollution.

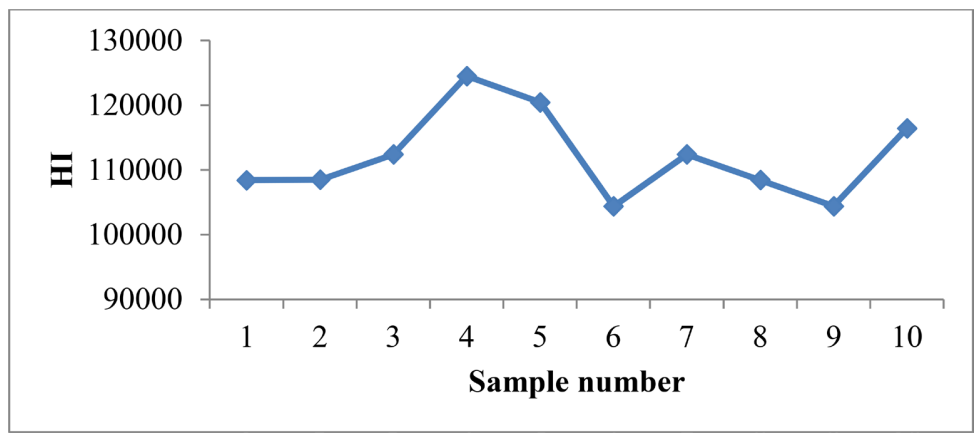

Figure 6. The hazard index of trace elements in Douala groundwater.

Table 7. Classification of hazard risk assessment of the water samples.

\begin{tabular}{ccccc}
\hline INDEX & Range & Classification & Samples & $\%$ \\
\hline CR & $>10^{-4}$ & Intolerable & 10 & 100 \\
HQ & $>1$ & No carcinogenic adverse effects & 10 & 100 \\
HI & $>1$ & Unsafe & 10 & 100 \\
\hline
\end{tabular}

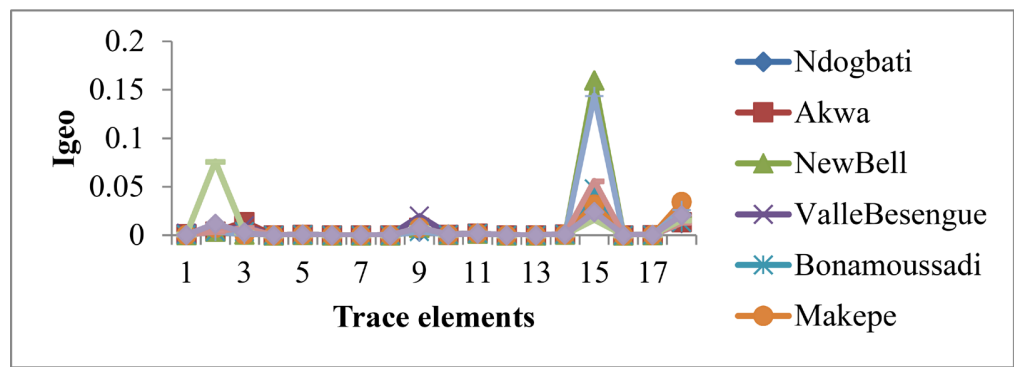

Figure 7. The geo-accumulation index of trace elements of groundwater in Douala. 


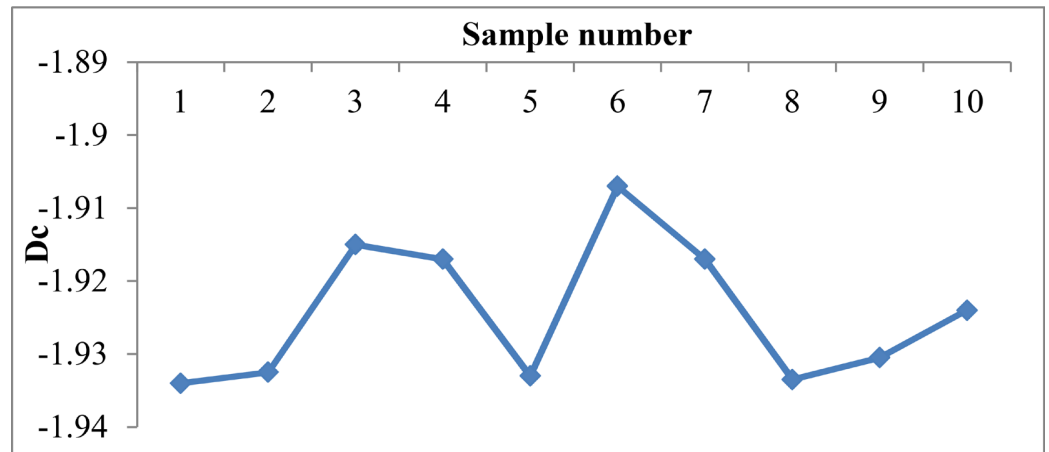

Figure 8. The degree of contamination of trace elements of groundwater Douala.

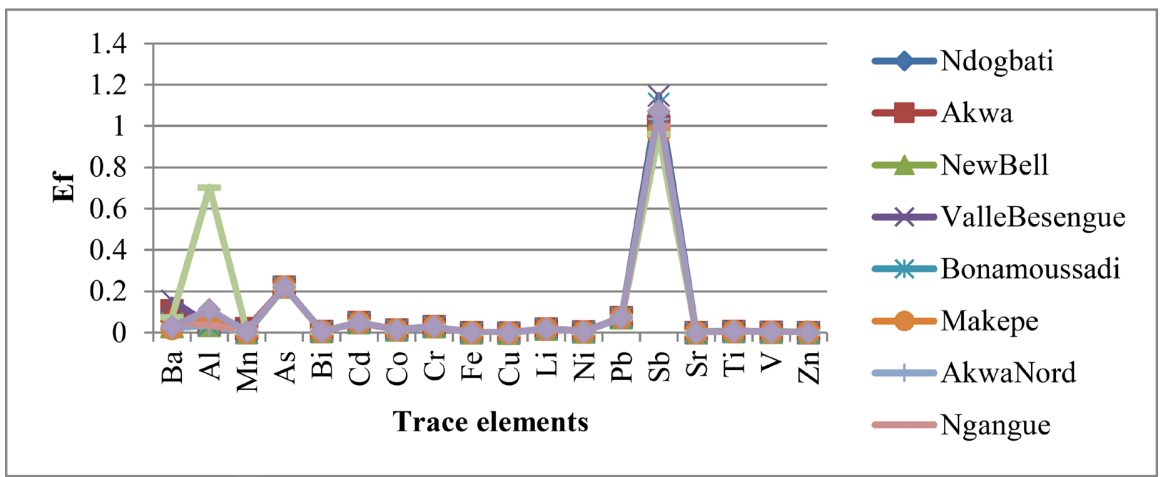

Figure 9. The enrichment factor for trace elements of groundwater in Douala.

3) Enrichment factor (EF) sequence in the sediments was $\mathrm{Pb}>\mathrm{Sr}>\mathrm{Ba}>\mathrm{Mn}>$ $\mathrm{Bi}>\mathrm{Co}>\mathrm{Fe}>\mathrm{Li}>\mathrm{V}$ (Figure 8). Significant enrichment ranged from $0-1.2$ indicating that the sources of these elements are not from rock weathering processes (geogenic). $\mathrm{Pb}$ and $\mathrm{Sr}$ are the most abundant in all the groundwater in Douala; this could be attributed to agricultural and industrial wastes. High values of Sb occurred at Akwa, Akwa Nord, New Bell and Ndogbati; Al at Bepanda and As Akwa, Makepe Deido as in Figure 9.

4) Pollution Load Index (PLI) values of indicated that $80 \%$ of the trace elements in the groundwater in Douala were $<1$ therefore considered unpolluted, and $20 \%$ were $=0$, which is indicative of perfection, meaning there is no pollution in the groundwater as in Figure 10. Pollution load index measured the pollution severity and its variation in the groundwater in the various localities in Douala. This index is a quick tool used to compare the pollution status of different locations in a study area [33].

5) Ecological Risk assessment Er of the trace elements in the groundwater of Douala is given in Figure 11. All values showed low potential ecological risk, (Er $<40$ ) indicating low pollution according to [34]. Steps should be taken to minimize contamination.

6) Ecological risk index (RI) of the trace elements in groundwater ranged from -17.58 to -17.64 as in Figure 12 classifying groundwater in Douala as being of low ecological risk, [34]. RI varies with time depending on activities in the various ecological niches in the area. 


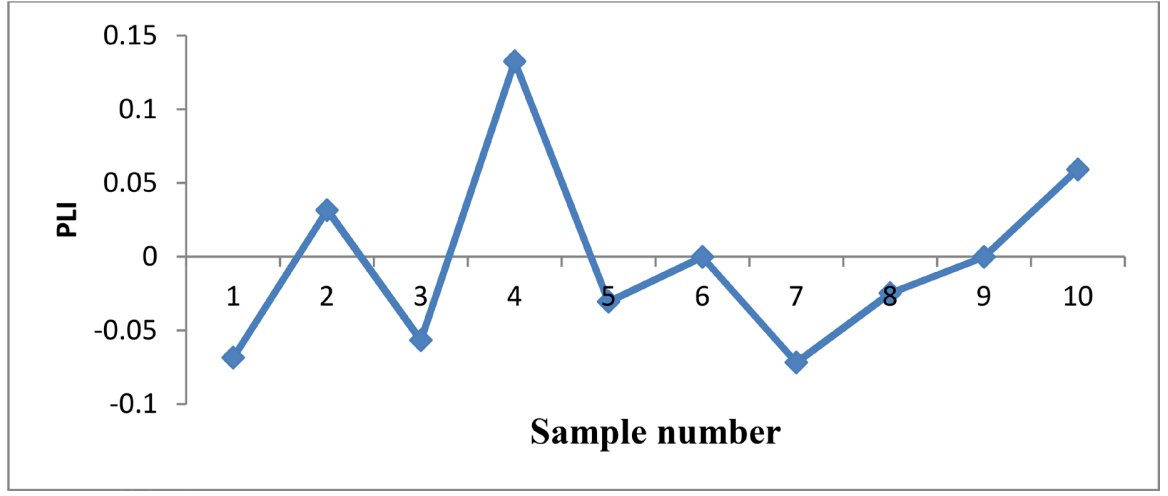

Figure 10. The pollution load index of trace elements of groundwater in Douala.

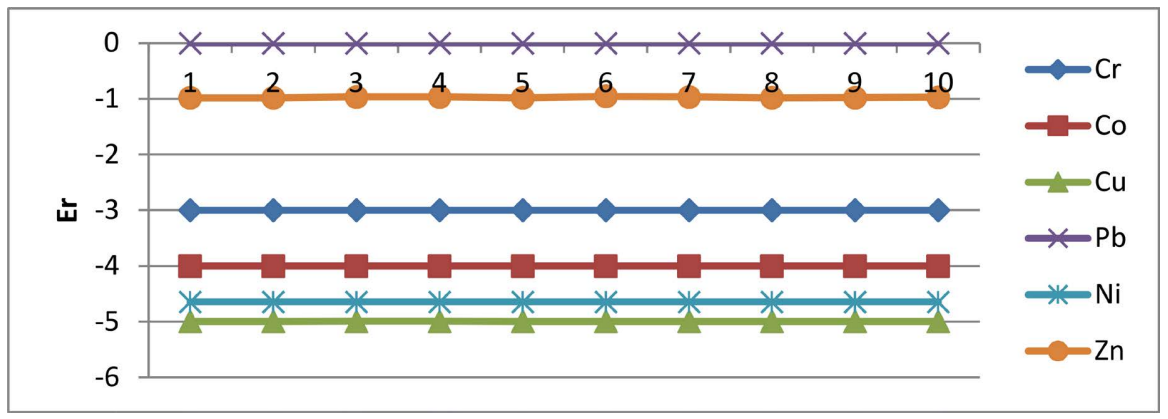

Figure 11. Ecological risk factor of trace elements of groundwater in Douala.

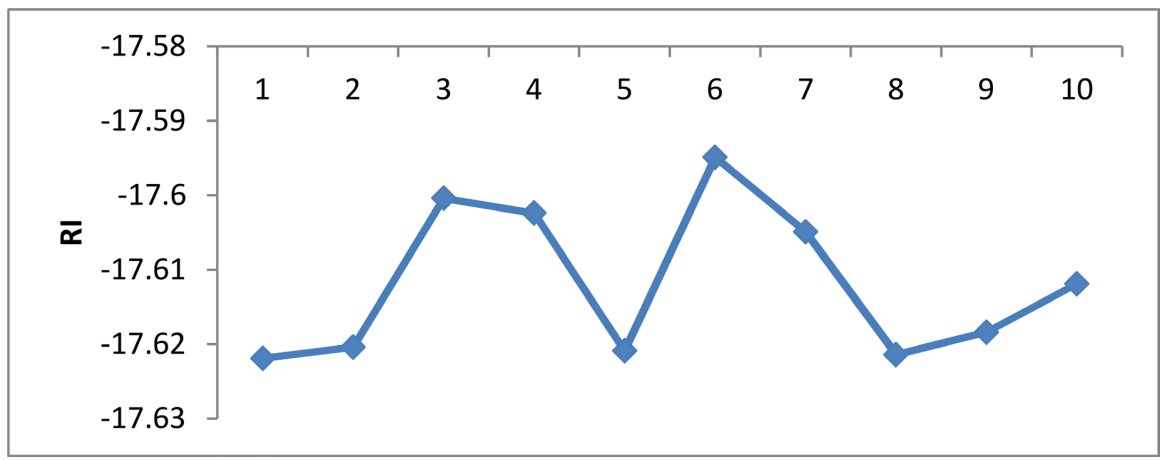

Figure 12. Ecological risk index of trace elements in Douala.

Table 8. Classification of pollution indices for Groundwater in Douala.

\begin{tabular}{ccccc}
\hline INDEX & Range & Classification & Samples & $\%$ \\
\hline DC & $<10$ & Low degree of contamination factor & 10 & 100 \\
EF & $\leq 1$ & Background contamination & 2 & 20 \\
& $1-2$ & Minimal enrichment & 8 & 80 \\
Er & Er $<40$ & Low potential risk & 10 & 100 \\
RI & RI $<150$ & Low ecological risk & 10 & 100 \\
PLI & $=0$ & perfection & 2 & 20 \\
& $<1$ & No pollution & 8 & 80 \\
Igeo & $0-1$ & Unpolluted to moderately polluted & 10 & 100 \\
\hline
\end{tabular}


A classification of all the pollution indices for groundwater in Douala is presented in Table 8.

\subsection{Statistical Analysis}

1) Pearson's Correlation Analysis (PCA). The Pearson's correlation matrix (Table 9) exhibited very strong positive correlation exists between the following; $\mathrm{Fe}$ and $\mathrm{Ba}(\mathrm{r}=0.84), \mathrm{Cu}$ and $\mathrm{Si}(\mathrm{r}=0.80)$ and TDS and EC $(\mathrm{r}=1)$. Strong positive correlation existed between $\mathrm{Mn}$ and $\mathrm{Ba}(\mathrm{r}=0.74)$, $\mathrm{Sb}$ and $\mathrm{Si}(\mathrm{r}=0.70)$. Good positive correlation existed between $\mathrm{Cu}$ and $\mathrm{Fe}(\mathrm{r}=0.68)$, and an average correlation existed between $\mathrm{Sb}$ and $\mathrm{Cu}(\mathrm{r}=0.50)$. Very strong negative correlation existed between $\mathrm{pH}$ and temperature $(\mathrm{r}=-0.80)$ as in Table 9 .

\section{2) Hierarchical cluster Analysis}

(HCA) was conducted based on the normalized data along with Ward's linkage method. The R-mode cluster analysis performed on the groundwater analysis produced a Dendrogram Figure 13 has two clusters based on similarities and dissimilarities. Cluster1 comprised of $\mathrm{Si}$ and cluster 2 comprised of two sub clusters; Sub-clusters1; Sb and Sub-clusters which is divided into two classes: Class1; Sb and Class2; TI, V, Ti, Sn, Pb, Mo, Ni, Ag, Cd, Co, Cu, U, Y, Ba, Mn, $\mathrm{Cr}, \mathrm{Se}, \mathrm{Bi}, \mathrm{As}, \mathrm{Fe} \mathrm{Li}, \mathrm{Zn}, \mathrm{Sr}, \mathrm{Al}$. as seen in Figure 13.

The elements in Cluster2 Class2 associate with one another because they are from the same parent rocks, which could possibly be that they resulted from the same, melt during crystallization. Sb and Al have different mobility Si also clustered

Table 9. Correlation matrix for the field physicochemical parameters and Trace elements.

\begin{tabular}{|c|c|c|c|c|c|c|c|c|c|c|c|c|c|c|}
\hline & $\mathrm{Ba}$ & $\mathrm{Al}$ & $\mathrm{Mn}$ & $\mathrm{Si}$ & $\mathrm{Fe}$ & $\mathrm{Cu}$ & $\mathrm{Sb}$ & $\mathrm{Sr}$ & $\mathrm{U}$ & $\mathrm{Zn}$ & $\mathrm{T}\left({ }^{\circ} \mathrm{C}\right)$ & $\mathrm{pH}$ & $\mathrm{EC}$ & TDS \\
\hline $\mathrm{Ba}$ & 1 & & & & & & & & & & & & & \\
\hline $\mathrm{Al}$ & 0.068 & 1 & & & & & & & & & & & & \\
\hline Mn & 0.748 & -0.189 & 1 & & & & & & & & & & & \\
\hline $\mathrm{Si}$ & 0.440 & -0.149 & 0.044 & 1 & & & & & & & & & & \\
\hline $\mathrm{Fe}$ & 0.848 & 0.000 & 0.461 & 0.474 & 1 & & & & & & & & & \\
\hline $\mathrm{Cu}$ & 0.487 & -0.197 & 0.072 & 0.809 & 0.685 & 1 & & & & & & & & \\
\hline $\mathrm{Sb}$ & 0.485 & -0.402 & 0.181 & 0.709 & 0.463 & 0.507 & 1 & & & & & & & \\
\hline $\mathrm{Sr}$ & -0.385 & -0.315 & -0.428 & 0.207 & -0.283 & 0.359 & 0.042 & 1 & & & & & & \\
\hline $\mathrm{U}$ & -0.193 & 0.473 & -0.339 & -0.295 & -0.032 & -0.348 & -0.077 & -0.128 & 1 & & & & & \\
\hline $\mathrm{Zn}$ & -0.070 & -0.188 & -0.444 & 0.224 & 0.326 & 0.452 & 0.066 & 0.376 & 0.071 & 1 & & & & \\
\hline $\mathrm{T}\left({ }^{\circ} \mathrm{C}\right)$ & 0.159 & -0.008 & 0.198 & 0.207 & -0.055 & 0.112 & 0.424 & 0.375 & 0.168 & -0.373 & 1 & & & \\
\hline $\mathrm{pH}$ & -0.456 & -0.249 & -0.372 & 0.040 & -0.242 & -0.035 & -0.279 & -0.081 & -0.312 & 0.272 & -0.808 & 1 & & \\
\hline EC & -0.036 & -0.344 & 0.089 & 0.176 & -0.021 & 0.400 & 0.134 & 0.324 & -0.597 & -0.233 & 0.282 & -0.028 & 1 & \\
\hline TDS & -0.034 & -0.344 & 0.090 & 0.176 & -0.021 & 0.401 & 0.131 & 0.327 & -0.602 & -0.233 & 0.279 & -0.027 & 1.00 & 1 \\
\hline
\end{tabular}

0.8 - 1.00 Very strong correlation; 0.7 Strong correlation. 


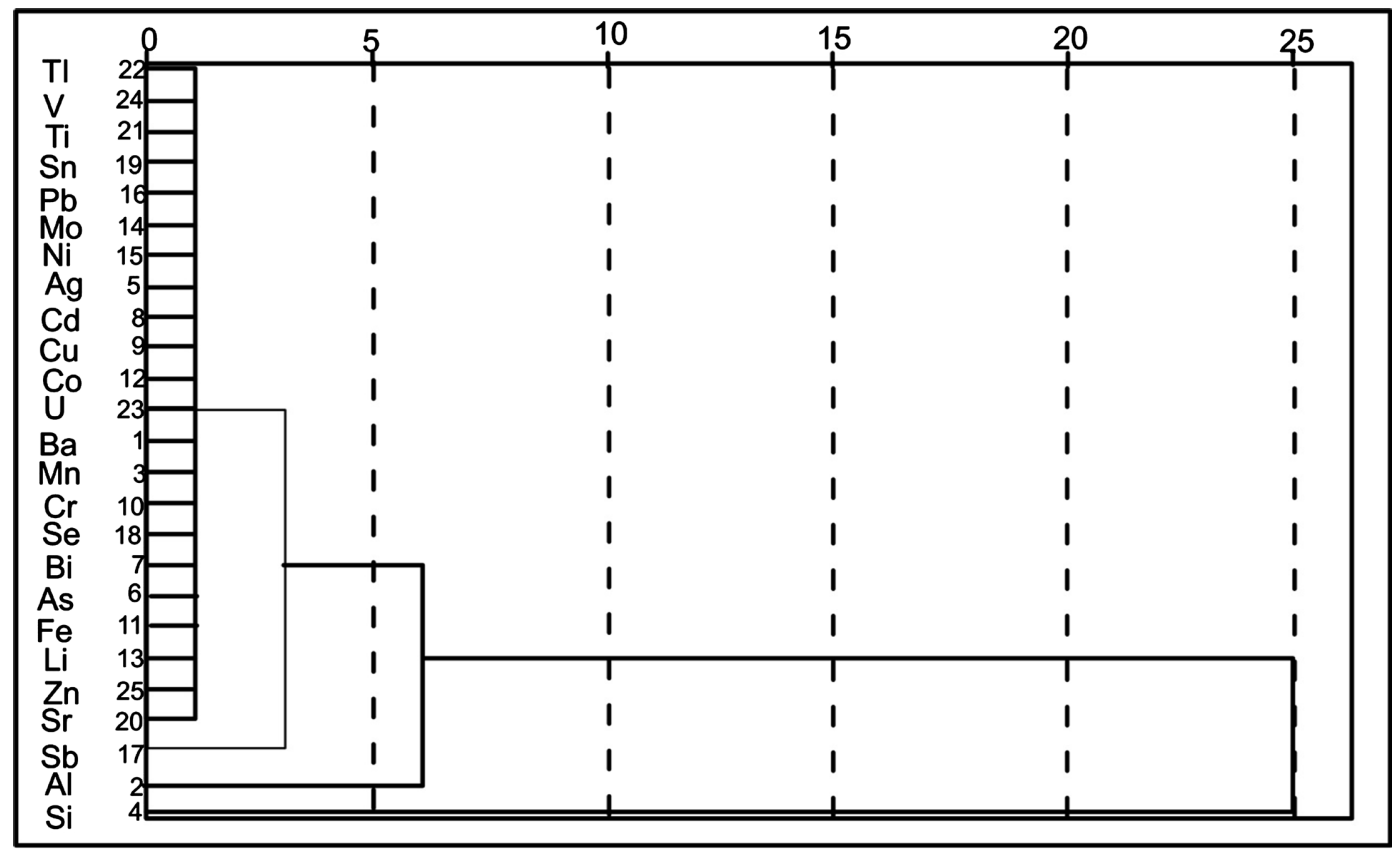

Figure 13. Dendrogram of trace elements in Douala groundwater.

together but in different subclasses which indicates that they also emanate from same parent rock. The presence of Si in Cluster1 reveals lithogenic contribution from environmental processes and thus of a different provenance. This is due to the marked difference in their thermal stability and chemical activity.

The concentration of trace elements in water could be influenced by natural and anthropogenic factors. Naturally, trace elements are associated with different rock types in varying degrees with $\mathrm{Cr}, \mathrm{V}, \mathrm{Ni}, \mathrm{Co}, \mathrm{Cu}, \mathrm{Fe}$, commonly associated with low silica content rocks [34]. The most likely mode of occurrence of trace elements in groundwater within the study area is geogenic with slightly elevated concentrations of $\mathrm{Sr}, \mathrm{Ba}$, and $\mathrm{Li}$.

\section{Conclusions}

The trace elements detected in groundwater in Douala and their relative abundance in decreasing order are: $\mathrm{Si}>\mathrm{Al}>\mathrm{Sb}>\mathrm{Sr}>\mathrm{Ba}>\mathrm{Mn}>\mathrm{Li}>\mathrm{Zn}>\mathrm{As}>\mathrm{Bi}>$ $\mathrm{Cr}>\mathrm{Fe}>\mathrm{Se}>\mathrm{Ag}>\mathrm{Mo}>\mathrm{Ni}>\mathrm{Pb}>\mathrm{Sn}>\mathrm{Ti}>\mathrm{TI}>\mathrm{V}$.

Health risk assessment qualified groundwater in Douala as unsafe and intolerable for human consumption but without carcinogenic effects.

Pollution indices placed groundwater in Douala in the low degree background contamination with minimal enrichment, low potential ecological risk and geogenically unpolluted to moderately polluted

Very strong correlations were observed among some of the trace element pairs, suggesting common sources, mutual dependence and identical behaviour from provenance and during transport.

The severity of trace element toxicity is governed by several factors, such as dose, nutrition, age, and even life style. Therefore, these low trends might not 
guarantee human health risks due to an increasing level of environmental pollution that might be imposed by increasing human activity in Douala City and environs; groundwater might become contaminated; this demands for monitoring of groundwater sources for drinking purposes.

\section{Acknowledgements}

The authors acknowledge the reviewers of the manuscript whose corrections improved the paper immensely.

\section{Conflicts of Interest}

The authors declare no conflicts of interest.

\section{References}

[1] Akoachere, R.A., Egbe, S.E., Eyong, T.A., Edimo, S.N., Longonje, S.N., Tambe, D.B. and Nelly, N.B. (2019) Seasonal Variations in Groundwater of the Phreatic Aquiferous Formations in Douala City-Cameroon: Hydrogeochemistry and Water Quality. Open Access Library Journal, 6, e5328.

[2] Guevart, E., Noeske, J., Ekambi, A., Solle, J. and Bita Fouda, A. (2006) L’amélioration de la qualité par l'analyse des décès au cours de l'épidémie de choléra de 2004 à Douala. Cahier de Santé, 16, 49-154. (in French)

[3] Mehri, A. and Marjan, R.F. (2013) Trace Elements in Human Nutrition: A Review. International Journal of Medical Investigation, 2, 115-128.

[4] Marschner, H. (1995) Mineral Nutrition in Higher Plants. 2nd Edition, Academic, London. https://doi.org/10.1016/B978-0-12-473542-2.X5000-7

[5] Akoachere, J.F.T.K., Lundi, A. and Njinuwo, M.T. (2013) Assessment of the Relationship between Bacteriological Quality of Dug-Wells, Hygiene Behaviour and Well Characteristics in Two Cholera Endemic Localities in Douala, Cameroon. BMC Public Health, 13, Article No. 692. https://doi.org/10.1186/1471-2458-13-692

[6] Eneke, G.T., Ayonghe, S.N., Chandrasekharam, D., Ntchancho, R., Ako, A.A., Mouncherou, O. and Thambidurai, P. (2011) Controls on Groundwater Chemistry in a Highly Urbanised Coastal Area. International Journal of Environmental Research, 5, 475-490.

[7] Societe National des Hydrocarbure (SNH) (1999) The Douala/Kribi Campo Basin. Republic of Cameroon, Third Licensing Round: Report 4/8.

[8] Mural, R.C. (1972) Stratigraphy and Paleogeography of the Cretaceous and Lower Tertiary in Southern Nigeria. In: Dessauvagie, T.F.J. and Whiteman, A.J., Eds., $A f$ rican Geology, University of Ibadan Press, Ibadan, 251-266.

[9] Petters, S.W. (1980) Biostratigraphy of Upper Cretaceous Foraminifera of the Benue Trough, Nigeria. Journal of Foraminiferal Research, 10, 191-204. https://doi.org/10.2113/gsjfr.10.3.191

[10] Reyment, R.A. (1955) The Cretaceous Ammonites of Southern Nigeria and Southern Cameroon. Bulletin No. 25, Geological Survey of Nigeria, Abuja, 112 p.

[11] Nodesa, C. (1971) Lexicon of West Africa Stratigraphic Names (from Togo to Angola). HTCS Report 443 N0010.

[12] Abbot, B.M., Walker, J.W. and Prissorsky, J.A. (1978) An Evaluation of the Douala Permit, Cameroon, as an Aid to the 1978 Relinquishment. HTSC Report No. 442A1822, 25 p. 
[13] Belinga, E.S.M. (1984) Geology of Cameroon. University of Yaounde, Yaounde.

[14] Njike, N.P.R. (1984) Contributions a l'etude geologique, stratigraphic et structural de la bordure, thèses. Department of Geology, University of Yaounde, Yaounde, 61.

[15] Nguene, F.R., Tanfu, S., Loule, J.P. and Nhassa, C. (1992) Paleoenvironment of the Douala/Kribi Campo Sub-Basins in Cameroon, West Africa. African Geology, University of Yaounde, Yaounde.

[16] Njoh O.A., Essien J.A. and Tembi, A. (2014) Albian-Turonian palynomorphs from the Mundeck and Logbajeck Formations, Ediki River, North-Western Part of the Douala Sub-, Cameroon. Science, Technology and Development, 15, 66-77.

[17] Ji, Y., Feng, Y., Wu, J., Zhu, T., Bai, Z. and Duan, C. (2008) Using Geo-Accumulation Index to Study Source Profiles of Soil Dust in China. Journal of Environmental Sciences, 20, 571-578. https://doi.org/10.1016/S1001-0742(08)62096-3

[18] Akoachere II, R.A., Hosono, T., Eyong, T.A., Ngassam, M.C.P., Nkongho, R.N., Okpara, S.O. and Oben, T.T. (2019) Evaluation of Trace Metals in Groundwater of Ekondo-Titi and Environs, Onshore Rio Del Rey, Cameroun. Open Access Library Journal, 6, 1-25.

[19] Paustenbach, D.J. (2002) Human and Ecological Risk Assessment: Theory and Practice. 1st Edition, John Wiley and Sons, New York.

[20] Hu, X., Zhang, Y., Ding, Z.H., Wang, T.J., Lian, H.Z. and Sun, Y.Y. (2012) Bio-Accessibility and Health Risk of Arsenic and Heavy Metals (d, Co, Cr, Cu, Ni, Pb, Zn and $\mathrm{Mn}$ ) in TSP and PM2.5 in Nanjing, China. Atmospheric Environment, 57, 146152. https://doi.org/10.1016/j.atmosenv.2012.04.056

[21] Lushenko, M.A. (2010) A Risk Assessment for Ingestion of Toxic Chemicals in Fish from Imperial Beach. San Diego State University, San Diego.

[22] Koki, I.B., Bayero, A.S., Umar, A. and Yosuf, S. (2015) Health Risk Assessment of Heavy Metals in Water, Air, Soil and Fish. African Journal of Pure and Applied Chemistry, 9, 204-210. https://doi.org/10.5897/AJPAC2015.0654

[23] Kamunda, C., Mathuthu, M. and Madhuku, M. (2016) Health Risk Assessment of Heavy Metals in Soils from Witwatersrand Gold Mining Basin, South Africa. International Journal of Environmental Research and Public Health, 13, Article No. 663. https://doi.org/10.3390/ijerph13070663

[24] Song, D., Zhuang, D., Jiang, D., Fu, J. and Wang, Q. (2015) Integrated Health Risk Assessment of Heavy Metals in Suxian County, South China. International Journal of Environmental Research and Public Health, 12, 7100-7117. https://doi.org/10.3390/ijerph120707100

[25] Kim, E.J., Herrera, J.E., Huggins, D., Braam, J. and Koshowki, S. (2011) Effect of pH on the Concentrations of Lead and Trace Contaminants in Drinking Water: A Combined Batch, Pipe Loop and Sentinel Home Study. Water Research, 45, 2763-2774. https://doi.org/10.1016/j.watres.2011.02.023

[26] Boateng, T.K., Opoku, F., Osafo, S.A. and Osei, A. (2015) Pollution Evaluation, Sources and Risk Assessment of Heavy Metals in Hand-Dug Wells from Ejisu-Juaben $\mathrm{Mu}$ nicipality, Ghana. Environmental Systems Research, 4, Article No. 18. https://doi.org/10.1186/s40068-015-0045-y

[27] Kolluru, R.V., Bartell, S.M., Pitblado, R.M. and Stricoff, R.S. (1996) Risk Assessment and Management Handbook. McGraw-Hill, New York.

[28] Adebowale, K.O., Agunbide, F.O. and Olu Owolabi, B. (2009) Trace Metal Concentration, Site Variations and Partitioning Pattern in Water and Bottom Sediments from Coastal Area: A Case Study of Ondo Coast, Nigeria. Environmental Research Journal, 3, 46-59 
[29] Ayantobo, O.O., Awomeso, J.A., Oluwasanya, G.O., Bada, B.S. and Taiwo, A.M. (2014) Non-Cancer Human Health Risk Assessment from Exposure to Heavy Metals in Surface and Groundwater in Igun Ijesha, Southwest Nigeria. American Journal of Environmental Science, 10, 301-311. https://doi.org/10.3844/ajessp.2014.301.311

[30] World Health Organization (2017) Guidelines for Drinking-Water Quality: 4th Edition Incorporating the First Addendum. World Health Organization, Geneva.

[31] U.S. Environmental Protection Agency (2013) 2011 Toxics Release Inventory: Public Data Release Report. U.S. Environmental Protection Agency, Washington DC.

[32] Akoachere, R.A., Etone, E.N., Mbua, R.L., Ngassam, M.P., Longonje, S.N., Oben P.M. and Engome, R.W. (2019) Trace Metals in Groundwater of the South Eastern Piedmont Region of Mount Cameroon: Quantification and Health Risk Assessment. Open Access Library Journal, 6, 1-21

[33] Ian Ridley, W. (2012) Chap 15. Petrology of Associated Igneous Rocks. In Volcanogenic Sulphide Occurrence Model, U.S. Geological Survey, Reston, 227-262.

[34] Hakanson, L. (1980) An Ecological Risk Index for Aquatic Pollution Control: A Sedimentological Approach. Water Research, 14, 975-1001.

https://doi.org/10.1016/0043-1354(80)90143-8 